\title{
A STUDY TO ASSESS THE EFFECTIVENESS OF YOGA THERAPY ON THE LEVEL OF STRESS AMONG CHRONICALLY HOSPITALISED PATIENTS INA SELECTED HOSPITAL
}

* Prof. Mrs. V. Hemavathy, *** Mr. Suresh Babu and *** Mrs. Ajitha Kumari. Abstract

Stress is a universal phenomenon and an important component in our life. Yoga is one of the few stress relief tools that have a positive effect on all the body systems involved in body age. Yoga should be made accessible and relevant to anybody so that anyone with the desire can practice yoga. Yoga in this approach can be adapted to the individual requirements, needs and goals age and health capability which denotes that there is no barrier at all. A study was conducted to examine the effectiveness of yoga therapy on the level of Stress among Chronically hospitalised patients in a selected hospital. Quasi experiment one group pre test post test design was found to be appropriate to meet the objectives of the study. The sample size of the present study was 60 hospitalized patients and they were selected through stratified random sampling technique. They were asked to complete the geriatric stress scale and the scores were analysed. Yoga therapy was implemented to the patients for a period of three weeks. A post test was conducted to assess the effectiveness of the intervention. Appropriate statistical technique was employed to test the hypothesis and to analyse the findings. The result showed that there is a significant decrease in the level of stress among the hospitalized patients after implementing yoga therapy. The study revealed that the yoga therapy was found to be effective on the level of stress among chronically hospitalized patients in selected hospital.

Keywords : Yoga therapy, stress, institution and hospitalized patients.

\section{Introduction}

Yoga is like a music. The rhythm of the body. The melody of mind and harmony of the soul, create the symphony of the life. Yoga offers natural therapy for stress, because it activates the parasympathetic nervous system, the part of our nervous system responsible for relaxation and rejuvenation. Yoga builds greater inner calm, enabling you to deal with pressures and tension in a more constructive way. (Micheal S, 2008)

The center is funding research about yoga and its role in promoting wellness. Preliminary findings suggest that yoga helps to prevent heal or alleviate conditions such as heart disease, carpal tunnel syndrome, diabetes, high blood pressure. 
Stress among hospitalized patients the samples were 390 . Out of the 390 who were screened showed evidence of stress. Half of these were suffering from an affective psychosis Kalpan et al (2006).

The state of the mind and that of the body are intimately related. If the mind is relaxed the muscles in the body will also be relaxed. Stress produces a state of physical and mental tension. Yoga, improves muscles strength, flexibility, blood circulation and oxygen uptake. In addition, the relaxation induced by meditation helps to stablize the autonomic nervous system with a tendency towards parasympathetic dominance. Physiological benefits which follow, help yog practitioners become more resilient to stressful conditions and reduce a variety of important risk factor for various diseases, especially cardio-respiratory diseases.

Arun et al (2008) conducted a study on living status and psychological well being. Social comparsion as a moderator in later life in Hong Kong, China. The findings suggest that although living alone is a risk factor for depression. In hospitalized patients, its negative effect can be reduced or even eliminated when downward social comparison or practiced.
Johnson (2007) described the social intimacy and stress in long term care facility residents. Twenty three participants aged 65 and older were selected from a hospital in north eastern India using convenience sampling techniques. They were asked to complete the survey the Miller social intimacy scale (MSIS).

\section{Material and Methods}

Stratified random sampling technique was adopted. Pilot study was conducted for two weeks to assess the feasibility and reliability of the tool. Sample of 60 hospialized patients people were selected and pre test was conducted using a stress assessment scale. The data collected was anlayzed and interpreted using the baseline date.

Scoring Procedure : The 30 items in section are built on a four point rating scale which has option such as not present, rare often and always with a score of 1,2,3, and 4 respectively.

$\begin{array}{lll}1-30 & : & \text { Normal } \\ 31-60 & : & \text { Mild Level of Stress } \\ 61-90: & \text { Moderate Level of Stress } \\ 91-120 & : & \text { Severe Level of Stress }\end{array}$


Assessment of Pre-Intervention level of stress in Hosptialized Patients $\mathbf{N}=\mathbf{6 0}$

\begin{tabular}{|l|l|l|}
\hline $\begin{array}{l}\text { Level of } \\
\text { Stress }\end{array}$ & Pre Test & \\
\hline & Frequency & Percentage \\
\hline Normal & Nil & Nil \\
\hline Mild & 311 & 52 \\
\hline Moderate & 23 & 18 \\
\hline Severe & 6 & 10 \\
\hline
\end{tabular}

\begin{tabular}{|l|l|l|l|l|}
\hline$(1-30)$ & & & & \\
\hline $\begin{array}{l}\text { Mild (31- } \\
60)\end{array}$ & 31 & 52 & 47 & 68 \\
\hline $\begin{array}{l}\text { Moderate } \\
(61-90)\end{array}$ & 23 & 38 & 7 & 12 \\
\hline $\begin{array}{l}\text { Severe } \\
(91-120)\end{array}$ & 6 & 10 & Nil & Nil \\
\hline
\end{tabular}

Majority of hospitalized patients has mild level of stress 31 (52\%), 23 (38\%) of people had moderate level of stress and $6(10 \%)$ of hospitalized patients had severe level of stress.

Assessment of Stress Level among

Hospitalized patient in Post Test

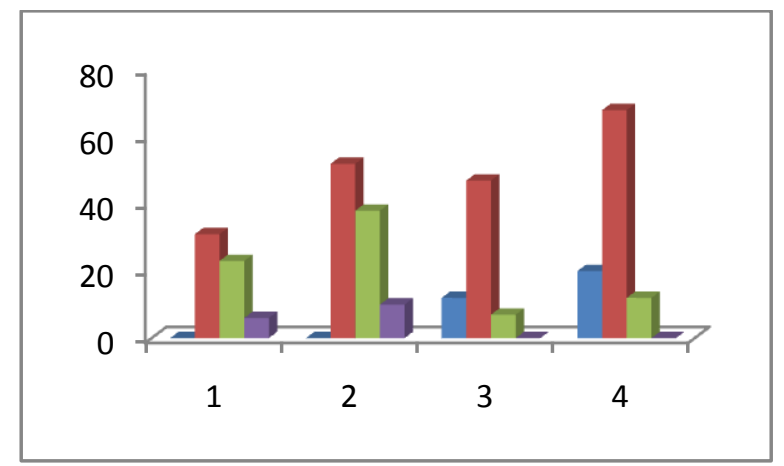

Comparison of Pre and Post Intervention

\section{Level of Stress}

\begin{tabular}{|l|l|l|l|l|}
\hline $\begin{array}{l}\text { Level of } \\
\text { Stress }\end{array}$ & $\begin{array}{l}\text { Pre } \\
\text { Test }\end{array}$ & $\begin{array}{l}\text { Post } \\
\text { Test }\end{array}$ & \\
\hline & No & $\%$ & No. & $\%$ \\
\hline Normal & Nil & Nil & 12 & 20 \\
\hline
\end{tabular}

In post test samples had normal level of stress. There is no normal level of stress in pre test. $31(52 \%)$ of them had mild level of stress in pre test. $41(68 \%)$ of them had mild level of stress in post test. In pre test $6(10 \%)$ had severe level of stress and there is no severe level of stress in post test.

Comparison of men and standard deviation of pre test and post test intervention level of stress.

\begin{tabular}{|l|l|l|}
\hline $\begin{array}{l}\text { Level of } \\
\text { Stress }\end{array}$ & $\begin{array}{l}\text { Pre } \\
\text { Interventon }\end{array}$ & $\begin{array}{l}\text { Post } \\
\text { Intervention }\end{array}$ \\
\hline Mean & 59.4 & 42.5 \\
\hline $\begin{array}{l}\text { Standard } \\
\text { Deviation }\end{array}$ & 19.9 & 16.7 \\
\hline
\end{tabular}

Hence these findings indicate that yoga therapy is significantly effective for reducing the stress among the hospitalized patients.

\section{Conclusion}

The present study assessed the effectiveness of yoga therapy on the level of stress among hospitalized patients in 
selected hospital. The results revealed that the yoga therapy was highly effective in the reduction of stress among the hospitalized patients with stress.

\section{Reference}

1. Arun G (2009) Stress Management and Yoga Therapy. Journal of Pyschiatric Nursing 65 (5) 65-67

2. Blazer D Yoga Therapy $6^{\text {th }}$ edition. Philadelphia. The American psychiatric publishing house : Text book of clinical psychiartry; P.No. 1534-1538.

3. Denise F. Nursing Research Principles and Methods. $7^{\text {th }}$ edition. Philadelphia Lippincott Williams and Wilkins 2005 chapter 17, research methodology p.no. 110-113.

4. Gurumani, An introduction of Biostatics $2^{\text {nd }}$ revised edition, Chennai mjp publishers.

5. Johnson, Psychiatric Mental health nursing, Adapatation and Growth. $7^{\text {th }}$ edition Philadelphia Lippincott Publications P. No. 129-134.
6. Lazarus, S. Principles and Practice of Psychiatric Nursing $4^{\text {th }}$ edition.Philadelphia : Mosby Publications 2009. Chapter 21, Principles of psychiatric Nursing : P. No. 317-322.

7. Kaplan and Saddock Complementary therapies in psychiatry $6^{\text {th }}$ edition Philadelphia, Lippincott publications, 2009 chapter 17, Comprehensive text book of Psychiatry : P. No. 2980-3012.

8. Micheal S. Psychiatric Nursing Contemporary $4^{\text {th }}$ edition., New Delhi Lippincott Williams and Wilkins Publications. Concepts of Mental Health Nursing P. No., 234235.

9. Ramana (2007), Stress and its Relationship to perceived health, Life Satisfaction and Morale in Older Adults. Issue of Mental Health Nursing, 11 (1) 17-31. 